\title{
なぜ日本語学習をやめてしまったのか \\ 一香港の社会人教育機関の学習者における動機減退要因の一事例一 Why they quit learning Japanese: \\ A case of demotivation of adult learners in Hong Kong
}

\author{
瀬尾匡輝 $/$ 陳德奇 $/$ 司徒棟威 \\ 香港理エ大学/香港大学専業進修学院/香港大学専業進修学院
}

\section{要旨}

本調查では、香港大学専業進修学院で初級日本語コースを受講したにも関わらず、途中で受講を やめてしまった学習者に対して質問紙調查と半構造化インタビューを行い、香港の生涯学習機関に おける社会人学習者の動機減退要因を探った。調查の結果、「仕事」と「時間」が原因で学習意欲 を減退させる調查協力者が多かった。仕事が忙しくなって予習・復習ができなくなり、日本語学習 を断念せざるを得ない状況が浮き彫りとなった。また、授業で取り扱う内容が多いため、ついてい けなくなったと語る調查協力者も多かったが、香港大学専業進修学院のカリキュラムは香港特別行 政区政府が定める持續進修基金に基づいて作成されており、カリキュラム改善の難しさも示唆され た。本稿では、Kubota（2011）の「娛楽と消費（Leisure/Consumption）」の概念を援用し、香港 における社会人日本語教育のあり方を検討する。

キーワード :

生涯学習、社会人教育、動機、動機減退要因 


\section{なぜ日本語学習をやめてしまったのか \\ 一香港の社会人教育機関の学習者における動機減退要因の一事例一}

\section{瀬尾匡輝 $/$ 陳德奇 $/$ 司徒棟威 香港理エ大学/香港大学専業進修学院/香港大学専業進修学院}

\section{1. はじめに}

香港の日本語教育の特徵として、語学学校、大学の公開講座、生涯学習機関といった初等・中 等・高等教育機関以外の機関で学ぶ日本語学習者が多いことがあげられる。その数は約 7 割強と存 在感を示しており（国際交流基金，2011）、これまでの香港の日本語学習熱を支えてきた。しかし ながら、近年その学習熱に陰りが見え始めてきた。香港大学専業進修学院を例にとると、2009年度 には約 1200 人ほどの学習者がゼロ初級のコースに在籍していたが、2010 年度には約 900 人と減少 し、今年度は約 400 人に減ってしまった1。韓国の音楽やドラマといったポップカルチャーの人気や 円高、東日本大震災の風評被害など社会的要素が関連しているかもしれないが、このような現状の 中で、今後香港における生涯学習機関では、日本語学習者減退の打開案を模索しなければならない。 これまでの香港の社会人教育における調查・研究は主に現在日本語コースを受講している学習者を 対象としており（e.g. 米本， 2009; 瀬尾，2011）、途中で日本語学習を断念してしまった学習者 の声が公になることはなかった。だが、筆者らが勤務する香港大学専業進修学院の初級日本語コー スではこれまで継続率は約 $60 \%$ にとどまり、約 4 割の初級学習者は日本語学習を途中で挫折してい る。学ぶ自由、やめる自由がある生涯学習機関で学ぶ学習者の動機減退要因を探ることは、今後の 香港における生涯学習としての日本語教育の調查や実践をしていく上で必要不可欠であると考えら れる。そこで、本調查では、香港大学専業進修学院で初級日本語コースを受講したにも関わらず、 途中で日本語学習に挫折してしまった学習者に対して質問紙調查と半構造化インタビューを行い、 香港の生涯学習機関における学習者の動機減退要因を探った。

\section{2. 先行研究}

第 2 言語を身につけようとする動機づけ（Motivation）にはWeiner (1992）の帰属理論、 Bandura（1997）の自己効力感理論、Covington（1998）の自己価値理論、Locke \& Latham

12009 年度、2010 年度の学習者数は 9 月開講のコース（週 1 回 3 時間 40 週）に加え、2 月開講 のコース（週 2 回 6 時間 20 週）も含んでいるが、2011 年度の学習者数は 9 月開講のコースのみで ある。そのため、2 月開講のコースで学習者数が増加することも期待される。しかし、2 月開講のコ 一スは週 2 回の短期集中コースということもあり、受講者数は例年 9 月開講のコースよりも少ない。 
（1990）の目標設定理論、Deci \& Ryan（1985）の自己決定理論など、動機づけという複雑な概念 を説明しようと試みた理論が数多くある（Dörnyei，2001a 参照）。その中でも、Dörnyei （2001a）は、教師がどのように学習者の動機を高められるのか教育実践の観点から理論構築を行っ ている。しかしながら、動機づけに関する理論構築・研究が行われる一方で、学習者の学ぶ意欲の 喪失や減退は、これまであまり注目されることがなかった。しかし、Zang（2007）が指摘するよう に、動機減退に関する知見が深まれば、逆に学習者の動機づけに生かせる可能性があるはずである。 そのような背景から、近年英語教育の分野では徐々に動機減退に関する調查が進められてきており、 Dörnyei（2001b）は動機減退を「行動の意志や進行中の行為において動機づけを低下させたり、縮 小させたりする特定の外的強制力」（p. 143 筆者訳）と定義している。 Nakata（2006）は学習者が動機を失っていく段階を 3 つに分類している（表 1 ）。

表 1 動機づけを失っていく段階（Nakata，2006 参照）

\begin{tabular}{|c|c|c|}
\hline Demotivation & Amotivation & Learned \\
Helplessness
\end{tabular}

Demotivation はもともとあったやる気が何らかのきっかけで減退、あるいはなくなっている状態 とし、Amotivationをこれまでの経験の積み重ねにより、期待できる結果が非現実的で、達成能力 がないと感じる状態としている。最も動機を失っている状態の Learned Helplessness では、全て のことに対し、無気力で何もしょうとしない状態だという。

また、垣田（1993）は学習意欲を高めたり、喪失させたりする要因を 3 つ挙げている（表 2 参 照）。

表 2 学習意欲を高めたり、喪失させたりする要因（垣田, 1993, p. 25)

\begin{tabular}{|l|l|}
\hline 環境の要因 & 社会環境、家庭環境、学校の物理的・精神的䨌囲気など \\
\hline 生徒自身の & 身体的・精神的健康、性格、情緒傾向、知能、適性、興味、態度、目的・到 \\
要因 & 達目標、欲求、学習の方法・習慣 \\
\hline 教授の要因 & 教材、教授法、教授の質、教師など \\
\hline
\end{tabular}

まず、学習する意欲を喪失させたり、減退させたりする環境要因として、学習者の社会的環境、家 庭的環境によるものがある。例えば、これまで香港の日本語学習者数は増加の一途を歩んできてい たが、ここ数年、韓国ドラマ・韓国音楽の人気や韓国企業の好景気により、韓国語学習者数が増加 し、日本語学習者が減退している現状がある。これは社会的環境が学習者の学習意欲を減退させて いることによると考えられる。また、家庭環境として、瀬尾（2011）は調査協力者の一人である香 港の社会人学習者が自身の娘の受験のために日本語学習を断念するなど、家庭での生活の変化によ り、日本語の学習が続けられなくなっていたと報告している。 
次に、「生徒自身の要因」が関係する意欲減退には、テストの結果の低さ（e.g. 山森，2004; Tsuchiya，2006）が関係していることが明らかになっている。大学 1 年生 129 人を成績の高低に分 け、学習意欲の減退を調査したTsuchiya（2006）は成績の良い学習者はテストなどの外的要因が意 欲減退の要因となり、成績の悪い学習者はテストに対する「自信のなさ」から意欲を減退させてい ると述べている。

さらに、これまでの動機減退要因に関する調查では、「教授の要因」に関係する意欲減退が最も 多く報告されている（e.g. 荒井，2004；Hasegawa，2004； Zhang，2007）。特に教師の態度が 大きく影響すると結論付けている研究が多く、Hasegawa（2004）は日本で英語を学ぶ中学・高校生 の多くがクラスの雾囲気に加え、教師に対する不満が最も大きな意欲減退の要因であると報告して いる。

しかし、これまで外国語学習における動機減退要因に関する研究はまだ少なく（荒井、2004）、 それらの研究は英語学習に限ったものが多い。また、中学・高校などの中等教育、大学などの高等 教育を取り扱った研究が中心であり、語学学校や生涯学習機関における調查は皆無である。生涯学 習機関で学ぶ社会人学習者には、学校教育のように試験や教室といった強制力が少なく、学びたい と思った本人が誰からも強制されることなく学習する（Knowles，1968）。その場合において、ど のような要因が学習者の動機を減退させるのか探ることは必要不可欠であろう。

\section{3. 調査の概要}

本調査は、生涯教育機関における社会人学習者の動機減退要因を探るため、2010 年度（2010 年 9 月から 2011 年 7 月まで）に香港大学専業進修学院の『日語入門』2コースで日本語を受講した学習 者のうち期末試験に申し込まなかった学習者 216 人（9 月開講 175 人、2 月開講 41 人）を対象に量 的・質的手法を用いて調查した。2010 年度の日語入門の受講者数は 908 人であり、557 人がコース 認定条件の要件を満たし修了している。コースを修了しなかった人数は 351 人であるが、本調查で は 2011 年 8 月に質問紙調査を実施したため、8 月の追試験、入学試験を受験し、日本語学習を続け る可能性があることを考慮し、期末試験に申し込まなかった学習者 216 人のみを対象とした

2 『日語入門』コースでは、年間 120 時間の授業時間で、『みんなの日本語』第 1 課から 20 課ま でを学習する。

3 期末試験の実施が 7 月に対し、申し込みが 4 月である。そのため、申し込みをしてから期末試験 までの間に学習者がやめることもある。本調査では、その学習者を含んでいない。 


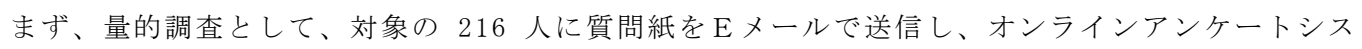
テム4を用いて回答してもらった。質問紙は日本語で作成し（資料 1 参照）、香港大学専業進修学院 のスタッフに中国語に翻訳してもらった。なお、質問紙に答えた調查協力者は 21 人であり、回収率 は 9.7\%と低い結果となった。

次に、質的調查としては、まず、質問紙にある調查協力者が記入した自由記述を分析した。その 後、質問紙調查に協力してくれた 21 人から 3 人を抽出し、2011 年 9 月に半構造化インタビューを

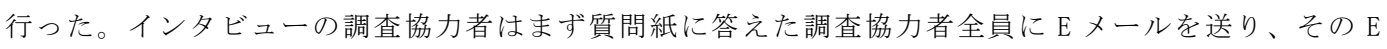
メールに返答してくれた 3 人を選んだ。つまり、筆者はそれがもたらす利便性や他のサンプルを用 いることが難しい場合の convenience sampling（Richards，2003）を採った。インタビューは英 語で実施し、『日語入門』コースでの困難、香港大学専業進修学院での日本語学習をやめてしまっ た理由、これからの予定などを聞いた。なお、本調査ではプライバシー保護のため、調查協力者の 名前を仮名とする。

以下に量的調查の協力者 21 人（表 3 参照）と質的調查の協力者 3 人（表 4 参照）のプロフィール を記す。

\section{表 3 量的調査協力者（21人）の属性}

性別：

\begin{tabular}{|c|c|}
\hline 女性 & 13 \\
\hline 男性 & 8 \\
\hline
\end{tabular}

出生地：

\begin{tabular}{|c|c|}
\hline 香港 & 19 \\
\hline 中国本土 & 2 \\
\hline
\end{tabular}

担当の先生：

\begin{tabular}{|l|c|}
\hline 日本人 & 12 \\
\hline 香港人 & 9 \\
\hline
\end{tabular}

年齢：

\begin{tabular}{|c|c|}
\hline 19 歳以下 & 0 \\
\hline $\begin{array}{c}20 \sim 24 \\
\text { 歳 }\end{array}$ & 1 \\
\hline $\begin{array}{c}25 \sim 29 \\
\text { 歳 }\end{array}$ & 6 \\
\hline $\begin{array}{c}30 \sim 34 \\
\text { 歳 }\end{array}$ & 7 \\
\hline $\begin{array}{c}35 \sim 39 \\
\text { 歳 }\end{array}$ & 4 \\
\hline $\begin{array}{c}40 \sim 44 \\
\text { 歳 }\end{array}$ & 0 \\
\hline $\begin{array}{c}45 \sim 49 \\
\text { 歳 }\end{array}$ & 2 \\
\hline $\begin{array}{c}50 \sim 54 \\
\text { 歳 }\end{array}$ & 0 \\
\hline $\begin{array}{c}55 \sim 59 \\
\text { 歳 }\end{array}$ & 1 \\
\hline
\end{tabular}

4 Survey Monkey (http:// surveymonkey.com/) 
瀬尾 匡輝／陳德奇／司徒 棟威：なぜ日本語学習をやめてしまったのか

一香港の社会人教育機関の学習者における動機減退要因の一事例一

表 4 質的調査協力者（3 名）のプロフィール

\begin{tabular}{|c|c|c|c|c|c|}
\hline 名前（仮名） & $\begin{array}{l}\text { 性 } \\
\text { 別 }\end{array}$ & 年齢 & 職業（役職） & 家族 & $\begin{array}{c}\text { 日本語学習を } \\
\text { やた時期 }\end{array}$ \\
\hline スコット & 男 & 50 代後半 & 会社員（マネジャー） & 妻と息子一人 & 36 週目 \\
\hline リリー & 女 & 30 代後半 & 無職 & 両親 & 5 週目 \\
\hline ロバート & 男 & 40 代後半 & インテリアデザイナー & シングル & 3 週目 \\
\hline
\end{tabular}

\section{4. 結果}

\section{1 量的データの分析}

質問紙調查では、1）性別や年齢などの調査協力者の属性、2）日本語学習を始めたきっかけ、 3 ）コースを途中でやめてしまった理由、4）今後の日本語学習の計画を聞いた（資料 1 参照）。 質問紙の各選択肢は、事前に香港大学専業進修学院で学ぶ初級日本語学習者 30 名に上記の質問に対 する答えを自由記述形式で書いてもらい、それを基に作成した。

まず、学習者がどのようなきっかけで日本語学習を始めたのかを報告する（表 5 参照）。

表 5 日本語学習を始めたきっかけ（複数回答可）

\begin{tabular}{|c|c|c|}
\hline 項目 & （人） & $(\%)$ \\
\hline 日本語でコミュニケーションができるようになりたい & 14 & 66.7 \\
\hline 日本旅行のため & 12 & 57.1 \\
\hline 日本が好きだから & 11 & 52.4 \\
\hline 日本の文化（文学や歴史）を知りたかった & 8 & 38.1 \\
\hline 今の仕事のため & 7 & 33.3 \\
\hline 昇進のため & 6 & 28.6 \\
\hline 日本との親善・交流のため（短期訪問） & 6 & 28.6 \\
\hline 日本の食べ物について知りたかった & 5 & 23.8 \\
\hline 国際理解・異文化理解の一環として & 4 & 19.0 \\
\hline 就職のため & 4 & 19.0 \\
\hline 日本のファッションについて知りたかった & 3 & 14.3 \\
\hline 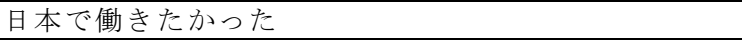 & 2 & 9.5 \\
\hline 日本の科学技術を知りたかった & 1 & 4.8 \\
\hline 家族・親族等周囲の人に勧められた & 1 & 4.8 \\
\hline
\end{tabular}

協力者らの日本語を学習する目的やきっかけは多様である。しかし、その中でも「日本語でコミ ユニケーションできるようになりたい」、「日本旅行のため」、「日本が好きだから」という項目 が本調査では上位に上がり、木山ら（2011）の香港の日本語学習者 1,123 人を対象に行った香港日 本語学習者背景調査と一致している。また、「今の仕事のため」、「昇進のため」といった現在の 職場での必要性に加え、「就職のため」といった将来への投資として日本語を学習していることも 窥われる。一方で、「大学や資格試験の受験の準備のため」、「日本へ留学のため」といった項目 は皆無であり、仕事をしている社会人学習者達は日本への留学は考えていないようであった。 
次に、香港に 31 の語学学校・生涯学習機関がある中で（国際交流基金，2011）、なぜ香港大学専 業進修学院を選んだのか尋ねた（表 6 参照）。

表 6 香港大学専業進修学院で日本語を勉強し始めたきっかけ（複数回答可）

\begin{tabular}{|l|c|c|}
\hline \multicolumn{1}{|c|}{ 項目 } & $($ 人) & $(\%)$ \\
\hline 上級まであった & 14 & 66.7 \\
\hline うちから近かった & 12 & 57.1 \\
\hline 会社から通うのに便利な場所だった & 6 & 28.6 \\
\hline 值段が安かった & 6 & 28.6 \\
\hline 通いやすい時間帯だった & 5 & 23.8 \\
\hline 友達に勧められて & 5 & 23.8 \\
\hline 香港大学付属の学校である & 5 & 23.8 \\
\hline 先生がいいと聞いた & 3 & 14.3 \\
\hline 週に1回3時間という授業の長さがよかった & 2 & 9.5 \\
\hline その他（香港大学専業進修学院で他の教科を学習していたから） & 1 & 4.8 \\
\hline
\end{tabular}

香港大学専業進修学院で日本語を勉強し始めたきっかけとして「上級まであった」という回答が 最も多かった。初級の段階ですでに上級まで日本語を学習しようと考えている学習者が多く、プロ グラムを選ぶ際の重要な要件となっていることが浮き彫りとなった。また、「うちから近かった」、 「会社から通うのに便利な場所だった」、「通いやすい時間帯だった」という項目も上位に位置づ けられており、社会人学習者ということから学習に費やせる時間が限られていることを考えると、 場所や時間が重要となるのは当然と言える。そのことからも「週 1 回 3 時間という授業の長さがよ かった」という学習者も少数ではあるがいた。

では、このようにある程度の強い目的や動機を持つ社会人学習者がなぜ日本語学習を途中で挫折 してしまったのか、本調査の課題である社会人学習者の動機減退要因について考察する。まず、各 学習者が香港大学専業進修学院の日本語コースに参加しなくなった時期を記入してもらった（表 7 参照）。

表 7 香港大学専業進修学院で日本語学習をやめてしまった時期

\begin{tabular}{|l|c|c|}
\hline \multicolumn{1}{|c|}{ 時期 } & (人) & (\%) \\
\hline $1 \sim 4$ 週目 & 1 & 4.8 \\
\hline $5 \sim 8$ 週目 & 2 & 9.5 \\
\hline $9 \sim 12$ 週目 & 4 & 19.0 \\
\hline $13 \sim 16$ 週目 & 0 & 0 \\
\hline $17 \sim 20$ 週目 & 5 & 23.8 \\
\hline $21 \sim 24$ 週目 & 2 & 9.5 \\
\hline $25 \sim 28$ 週目 & 6 & 28.6 \\
\hline $29 \sim 32$ 週目 & 0 & 0 \\
\hline $33 \sim 36$ 週目 & 0 & 0 \\
\hline $37 \sim 40$ 週目 & 1 & 4.8 \\
\hline
\end{tabular}


調査によると、25〜28 週目に受講をやめる学習者が最も多く、次に $17 \sim 20$ 週目となっている。 コースでは、25２8 週目の時期は『みんなの日本語初級』の第 $14 、 15$ 課（て形）を勉強している あたりであり、学習者が初めて動詞の活用を学習する。活用が導入され、学習者は難しさを感じ、 やめてしまうようである。また、17〜20 週目に受講をやめる原因としては 20 週目に中間試験があ り、中間試験への学習が追いつかず、途中で挫折してしまったのではないだろうか。

次に、学習者が香港大学専業進修学院での日本語学習をやめた理由を考察する（表 8 参照）。

表 8 香港大学専業進修学院での日本語学習をやめた理由（複数回答可）

\begin{tabular}{|c|c|c|}
\hline 項目 & (人) & $(\%)$ \\
\hline 仕事が忙しくなって、通えなくなった & 14 & 66.7 \\
\hline 学習ペースが速すぎた & 8 & 38.1 \\
\hline 定期テスト（中間テスト、クイズ）の成績が悪かった & 5 & 23.8 \\
\hline 3 時間のクラスは長すぎた & 5 & 23.8 \\
\hline クラスのレベルが高すぎる & 4 & 19.0 \\
\hline 勉強する内容が多すぎた & 3 & 14.3 \\
\hline 先生の説明がわかりにくかった & 3 & 14.3 \\
\hline 週 1 回の授業ではすぐ忘れてしまい、学習するのが困難だった & 3 & 14.3 \\
\hline 授業の進め方が単調だった & 3 & 14.3 \\
\hline 家庭の事情で、通えなくなった & 3 & 14.3 \\
\hline 仕事が変わって、通えなくなった & 2 & 9.5 \\
\hline 日本語の文法がわかりにくかった & 2 & 9.5 \\
\hline クラスの人数が多すぎて、十分練習できない & 2 & 9.5 \\
\hline 日本語の予習・復習方法が分からなかった & 2 & 9.5 \\
\hline 授業で扱う文型が難しかった & 2 & 9.5 \\
\hline 声に出して発音するのが恥ずかしかった & 1 & 4.8 \\
\hline 質問されて答えを間違えるのが嫌だった & 1 & 4.8 \\
\hline 単語を覚えるのが面倒だった & 1 & 4.8 \\
\hline 文法に関する学習が多かった & 1 & 4.8 \\
\hline 日本語能力試験のための勉強が多かった & 1 & 4.8 \\
\hline 教科書を暗記させられることが多かった & 1 & 4.8 \\
\hline 先生が生徒の間違いを馬鹿にした態度をとった & 1 & 4.8 \\
\hline 先生が感情的にどなったり、怒ったりした & 1 & 4.8 \\
\hline 授業で扱う文型がいつ使われるかわからなかった & 1 & 4.8 \\
\hline 授業で扱う内容に興味がなかった & 1 & 4.8 \\
\hline 友達と比べてテストの得点が取れなかった & 1 & 4.8 \\
\hline クラスメートが嫌いだった & 1 & 4.8 \\
\hline クラスの雰囲気が嫌だった & 1 & 4.8 \\
\hline 自分が目標としていた日本語能力を獲得できた & 1 & 4.8 \\
\hline 定期テスト（中間テスト、クイズ）の内容が実生活と結びつかない & 1 & 4.8 \\
\hline
\end{tabular}

やめた理由は学習者個人によって異なるため、一概には言うことができない。しかし、本調査で 最も多かったのは「仕事が忙しくなって、通えなくなった」である。他にも、「家庭の事情で、通 えなくなった」や「仕事が変わって、通えなくなった」など環境の要因が上位に位置づけられてお 
り、社会人学習者としては仕事や家庭といった社会的要因が大きいことが示唆される。次に多いの が「学習ペースが速すぎた」であり、他にも「3 時間のクラスは長すぎた」や「勉強する内容が多す ぎた」、「クラスの人数が多すぎて、十分練習できない」といったプログラムやカリキュラムの問 題もやめた一つの要因となっている。さらに、「定期テスト（中間テスト、クイズ）の成績が悪か った」や「日本語の予習・復習方法がわからなかった」という生徒自身の要因からやめる学習者も いた。

注目すべき点は、「クラスのレベルが高すぎる」、「勉強する内容が多すぎた」、「クラスの人 数が多すぎて、十分練習できない」、「日本語能力試験のための勉強が多かった」、「教科書を暗 記させられることが多かった」という声がある一方で、その逆の意見（例えば「クラスのレベルが 低すぎる」、「勉強する内容が少な寸ぎた」、「日本語能力試験のための勉強が少なかった」）が 全くなかったことである。このような点はカリキュラムや授業を設計する際に教師やプログラム運 営者が考慮しなければならないことであろう。

また、「日本語を学ぶ目的がわからなくなった」、「日本語に興味がなくなった」といった目的 や態度の面からの学習動機減退はなく、今後も日本語学習を続けたいと考えているようである。事 実、調查協力者に今後の日本語学習予定の有無を尋㸚たところ（表 9 参照）、「絶対にしない」と 回答した学習者は皆無であり、今後いずれかの形で学習したいと考えているようである。

\section{表 9 今後の日本語学習予定の有無}

\begin{tabular}{|l|c|c|}
\hline \multicolumn{1}{|c|}{ 項目 } & $($ 人) & $(\%)$ \\
\hline 絶対にする & 17 & 81.0 \\
\hline いつか時間があればしたい & 4 & 19.0 \\
\hline 絶対にしない & 0 & 0 \\
\hline
\end{tabular}

\section{2 質的データの分析}

\subsection{1 質問紙のコメント欄の分析}

次に、質問紙にある調查協力者が記入した自由記述欄を分析した。調査協力者が英語か広東語で 書いたコメントを筆者らが日本語に訳したものをここでは記す。

コメントを記入した学習者の多くは自身が習った教師に対して好意的な感想を述べていた。

先生（日本人）はとてもよくて、授業で日本の食べ物や生活様式を紹介してくれました。 (20 代後半 男性) 先生/校舎/教室環境/E ラーニングシステムはとてもいいと思いました。（20 代後半 男性） $X$ 先生 (日本人、男性) の教え方はとてもよかったです。親切だし、熱心だし、手助けをいっ もしてくれました。学生のために教材をいつもたくさん準備してくれたし、授業もとてもおも しろかったです。 （50代後半 女性） 仕事が忙しくて、途中でやめてしまいましたが、この9 月からもう一度受講したいと思いま す。その時はまた $Y$ 先生 (日本人、女性) のクラスに入りたいと思っていて、今授業のスケジ ュールを待っているところです。

Z先生 (香港人、男性) はとても親切で、頼りになりました。

（30 代後半 女性） (30 代前半 女性) 
しかしながら、教師に対して肯定的な声がある一方で、教師が教室内で使用する媒介語について 次のようなコメントがあった。

申し込む時は先生が英語で授業することを知りませんでした。そして、自分自身の英語の能力 は低く、授業についていくことは難しかったです。また、仕事が忙しくなり、クラスを1度久 席しただけで、ついていけなくなってしまいました。そのことを先生に伝えようと思いました が、自分の日本語や英語ではできず、だからあきらめてしまいました。（30代前半男性）

日本人の先生から授業を受けることは、正確な発音を聞くことができるし、日本人の先生は日 本の習慣についてもっと詳しく知っているので、授業がおもしろくなると思いました。しか し、特に入門コースでは、先生が広東語をある程度知っているほうがいいと思います。そし て、どんな先生が授業を教えるのか開始前に知っておきたいです。（30 代前半＼cjkstart男性）

このようにゼロ初級のクラスでは、広東語を使用しないことに難しさを感じている調査協力者が 多いことが窺えた。香港大学専業進修学院では、できるだけ日本語を使い授業を行うことを奨励し ているが、初級に関しては媒介語を使うことも認めている。その媒介語は教師により異なり、広東 語を使用する教師もいれば、広東語が話せない教師は英語や北京語を用い授業を行っている。香港 の現状として、英語を得意とする学習者がいる一方で、英語が話せず北京語が得意という学習者も いる。また、英語と北京語のどちらも話せない学習者もおり、広東語のみ話せる学習者もいる。媒 介語に関しては、広東語を使用するほうが学習者全体からの理解を得られるのかもしれない。

そして、調査協力者の多くが学習進度の速さと学習内容の多さに戸惑っているようであった。

余腵活動 (leisure) と考え学習していると、あまりにも内容が多すぎます。働きながらだと、 宿題やクイズ、陚験の勉強に費やす時間が限られてしまいます。（30 代前半 女性） 3 時間の授業時閒はあまりにも長いです。1回の授業で学ぶ内容が多くて、授業についていく ことができませんでした。1年閒授業が休みなく続くので、学習進度に追いつくために復習す ることもできません。 (20 代後半男性) 授業の時間が長いと思います。1 週間に2 回、1 回 1 時間半にするとよくなると思います。

(20 代後半 男性)

1 回 3 時間の授業は大変です。せめて 1 年閒 40 週のコースを 4 つに分け、 3 ケごとに区切 つて受講できるようにし、1回2 時間の授業にしたら、学生も復習の時間がとれるようになる 之思います。

(50 代後半 女性)

1 回のクラスで教科書 1 課を進むのは負担が大きすぎます。それに各課の文法が難しくなって いき、やめようと思いました。

（30 代前半 女性）

このように学習者の多くは、週 1 回 3 時間 40 週、合計 120 時間の授業時間に不満を抱いているよ うである。しかし、米本（2009）でも指摘されているが、この年間 120 時間という時間設定は、香 港特別行政区政府が一定の要件を満たす学習者に生涯教育のための費用を一部補助する持續進修基 金（Continuing Education Fund：以下 CEF）が関係している。CEF とは香港特別行政区に居住権 を持つ 18 歳から 65 歳を対象に、政府が認定するコースの受講にかかる費用の $80 \%$ 上限 1 万香港 
ドルまで補助する制度である。日本語のコースの場合、認定を受けるコースが年間 120 時間以上の 授業時間であることが必要である。そのため、香港大学専業進修学院では、働く社会人が週に複数 回受講することは難しいと考え、1 年間で 120 時間を消化するために週 1 回 3 時間の授業を組んで いる。質問紙調查では、確かに香港大学専業進修学院で日本語を勉強し始めたきっかけとして「週 に 1 回 3 時間という授業の長さがよかった」という声があったものの、学習者のコメント欄を分析 したところ、多くの学習者が年間 120 時間、特に週 1 回 3 時間という授業時間数では充分に復習す ることができず次第に授業についていけなくなり、学習動機を減退させる要因となっているようで あった。このように学習者のコメントを考慮すると、CEFの制度そのものを見直す必要に迫られてい ると言わざるを得ない。

また、米本（2009）でも同様に指摘されているが、学習進度に関しても CEF が大きな影響を与え ている。CEF の受給条件として、120 時間のコースに合格することに加え、指定の試験（e.g. 日本 語能力試験、BJT ビジネス日本語能力テスト）に合格しなければならない。香港大学専業進修学院の 場合、日本語能力試験がそのカリキュラムに大きな影響力を与えている（表 10 参照）。

表 10 香港大学専業進修学院のカリキュラム

\begin{tabular}{|c|}
\hline $\begin{array}{l}\text { 1年生 } \\
\text { ・『办んなの日本語』第1浬 20嘿 } \\
\text { ・120時間 }\end{array}$ \\
\hline
\end{tabular}

2 年生
・『水人な0日本語』第21 40浬
・120時間

\section{4主

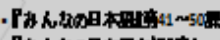

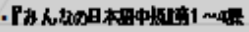
- 12006rin

\begin{tabular}{|c|c|c|c|c|c|}
\hline $\begin{array}{l}\text { 9月 } \\
\text { 開始 }\end{array}$ & $\begin{array}{ll}\text { 7月 } & \text { 9月 } \\
\text { 終了 } & \text { 開边 }\end{array}$ & $\begin{array}{l}\text { 12月 } \\
\text { JLPT }\end{array}$ & $\begin{array}{l}\text { 7月 } \\
\text { 終了 }\end{array}$ & $\begin{array}{l}\text { 9月 } \\
\text { 開始 }\end{array}$ & $\begin{array}{l}\text { 12月 } \\
\text { JLPT }\end{array}$ \\
\hline$\sum$ & 150 $\sim 160$ 時間 & $>$ & & ×280時間 & \\
\hline
\end{tabular}

現在の香港大学専業進修学院の初級日本語コースのカリキュラムは、旧日本語能力試験の 4 級 （現Ｎ５）が「日本語を 150 時間程度学習し、初級日本語コース前半を終了したレベル」と明記し てあるように、コース受講開始の翌年 12 月までに約 150 時間の日本語学習を終了する。使用するテ キストも『みんなの日本語』であり、第 1 課から 25 課までを 12 月の日本語能力試験に間に合うよ うに学習する。日本語能力試験を基準に考えれば、適当な時間設計であり、コース内容も妥当であ るのかもしれない。しかしながら、次の学習者のコメントを読む限りでは、学習者は必ずしも試験 のために日本語のコースを受講しているかといえば疑問が残る。

\footnotetext{
興味のためだけに日本語を学習しているにも関わらず、テストがあり大変でした。授業の内容 もテストの勉強ばかりで、いやになってしまいました。 (20代後半男性) クラスメートのほとんどが試験のために日本語を勉強しているようでした。（30代前半 女性 学生のレベルを維持するために、学校がテストをすることはわかります。しかし、働きながら 勉強していると、テストが大きな負担となってしまいます。テストの実施回数が少なくなると よくなると思います。

(20 代後半 男性)
} 
このように学習者の学習動機を減退させる一つの要因として試験がある。しかし、その試験とい うものが CEFに多大な影響を受けており、カリキュラム設計の可能性を結果的に限定している。

\subsection{2 半構造化インタビューの分析}

次に、質問紙調査に協力してくれた 21 人から 3 人を抽出し、初級日本語コースを受講しながらも、 何らかの理由でやめざるを得なかった学習者 3 名（スコット、リリー、ロバート）に半構造化イン タビューを行なった。まず、調查協力者 3 人の日本語の学習を始めたきっかけは「日本へ家族と旅 行することが多く、日本に興味があった（スコット）」、「生け花を 3 年前から香港で学んだり、 日本料理などの日本文化に興味があった（リリー）」、「生活の身の周りの日本製品から日本語に 興味を持った（ロバート）」などであり、日本への興味・関心から日本語を勉強し始めていた。こ のことは質問紙調查で最も回答が多かった項目と一致する。そして、日本語コースの受講をやめた 理由はどの調査協力者も「仕事」と「時間」が影響しているようであった。例えば、スコットは日 本語学習をやめた一番の理由を次のように語っている。

日本語を勉強し始めた最初の頃は、1 日 1〜2 時間勉強していましたが、それを毎日続ける ことは難しくなりました。7 時に仕事が終わって、家に帰り、夕食を食べて、家族と団樂す ると、それだけで 9 時から9 時半になってしまいます。それから、毎日 2 時間勉強しよう とすると、夜 11 時から 11 時半になってしまいます。毎日、それだけの時間を費やすこと は大変でした。

また、リリーも日本語コースの受講をやめた理由を

仕事が卅しくなったのがいちばんの理由です。あの時は毎日残業しなければならなくなっ て、授業に行くことができなくなってしまったし、授業の復習や予習もできなくなってし まいました。そうなると、授業についていけなくなって、結局やめざるをえなかったんで 才。

と語り、学習時間を取ることができなかったと語っている。そして、ロバートも

やめたのは、十分に準備をしないで授業へ行っていたからです。でも、每日仕事があって、 勉強する時間も十分なくて、ひらがな・カタカ十を覚えることができなくて、それで最初 からついていけなくなってしまったんです。

と予習・復習する時間を十分に取ることができなかったことで、ついていけなくなってしまったと 語っている。3人の調査協力者に、毎日どのくらい日本語を勉強しなければならなかったのかと尋ね たところ、どの協力者も「毎日 2 時間は勉強しなければ、授業についていくことは難しい」と述べ ていた。筆者らが香港大学専業進修学院で継続して日本語学習を続けている学習者に尋ねたところ、 「毎日約 2 時間勉強する」という声が返ってきた。この 2 時間というのが授業についていくための 必要最低限の学習時間のようであり、その時間を捻出できない学生にとっては非常に厳しいカリキ ユラムとなっているようである。 
そして、今後また日本語を勉強したいか尋ねたところ、「定年して、時間ができたら、日本語を 勉強したい（スコット）」、「今は無職で時間があるので、もう一度勉強したい（リリー）」、

「ひらがな・カタカナを覚えることができなくて挫折してしまったが、次はひらがな・カタカナを 自分で時間をかけて覚えて、もう一度日本語を勉強したい（ロバート）」と今後もまた日本語の学 習をしたいと述べていた。

\section{5. 考察}

これまでの動機減退要因に関する（特に、中等・高等教育機関で学ぶ学習者を対象とした）調査 では、「教授の要因」、特に教師の態度が大きく動機減退に影響を与えているという報告が最も多 かった。しかしながら、社会人学習者を対象とした本調査では、教師の態度が与える影響は少なか った。質問紙調查の中で、「先生が生徒の間違いを馬鹿にした態度をとった」や「先生が感情的に どなったり、おこったりした」といった項目に一人の調査協力者が回答していたが、多くの調査協 力者は自身が習った教師に対して好意的な意見を述べていた。香港大学専業進修学院で働く教師の 多くは経験豊富であり、香港の学習者に合わせ日々実践を行っている。また、学院側も定期的に教 師のための勉強会を開催し、教師自身が自己成長、自己研鑽できるように努めている。このことが 調査協力者からの肯定的評価へと繋がったのではないかと考える。

また、本調查に参加した調査協力者は「日本語を学ぶ目的がわからなくなった」、「日本語に興 味がなくなった」、「日本文化に興味がなくなった」といった目的や態度に関する動機減退要因は 皆無であり、今後も何らかの形で日本語学習を継続したいと考えていた。このことは、Nakata （2006）が明らかにした動機づけを失っていく段階の初期段階であり、日本語学習そのものに興味 を失っているわけではなかった。

本調査における動機減退要因は、社会人学習者ということもあり、仕事と勉強の両立を成り立た せることができなかったことが最も影響しているようであった。「余暇活動（Leisure）と考え（日 本語を）学習している」と述べている学習者にとっては、香港大学専業進修学院の学習進度は速す ぎるのかもしれない。そのため、十分な予習・復習の時間を取ることができず、授業についていけ なくなり、挫折してしまうのだろう。しかしながら、香港大学専業進修学院のカリキュラムは香港 特別行政区政府が定める CEF の受給条件を満たすために組まれており、CEF がその本来の目的であ る生涯教育の促進に寄与できているのか、再考の余地があると考えられる。今後、日本語コースの 受講を途中でやめてしまった学習者も満足できるように、従来の CEF の受給条件に囚われず、「余 暇活動」としての日本語教育を模索しなければならないのではないだろうか。 
これまでの生涯学習論を類別すると、1) 学習権的な生涯学習（学習を基本的人権の一つとして 捉え、社会的不平等を是正した社会参加を目指すもの）、2）職業再教育的な生涯学習（成人の職 業適用性のための再教育を中心にした生涯学習）、3）一般教養的な生涯学習（趣味、教養、文化、 スポーツ、余暇活動など非専門的、非職業的な生涯学習）に分けられる（瀬尾，2011）。言語教育 の分野においては、Norton Peirce（1995）が動機づけが社会における力関係とアイデンティティ、 言語学習という複雑な関係を捉え切れていないとし、学習者は力関係のある社会で何か見返りを期 待して投資すると考える社会的投資（Social Investment）という概念を提唱している。この考え 方では、言語学習者は特定の社会形態に関連して、異なった階級や集団を特徽付ける思考様式や知 識と定義される「文化資本（Cultural Capital）」を増加させることを目的とし、社会の中で力を 得るために言語を学習する。このことは生涯学習論の1) 学習権的な生涯学習と同じであり、ブラ ジルのFreire（1970）が貧困層、社会的不利益層の人間的な解放を目指すため識字教育を行ったよ うに、学習することによって力を持ったグループに所属できるという被抑圧者教育学と類似してい る。しかしながら、このような学習権的な生涯学習や社会投資としての言語学習は、香港のように 「余暇活動」として学ぶ日本語学習とは異なる。Kubota（2011）は日本の英会話学校の学習者、プ ログラム運営者にインタビュー調查を行い、分析した結果から「娛楽と消費（Leisure/Consumpti on）」としての語学学習という理論構築を行っている。Kubotaによれば、目標言語が教室外で使用 されることのない外国語環境下で学ぶ社会人学習者はすでに社会経済的地位を確立しているため、

「文化資本」を増大させる必要もなければ、生活に困るような状況もない。そのような場合、学習 者自身の余暇における満足感、楽しみ、喜びのための商品として語学学習を行い、語学の授業とい うサービスの消費を行っているのである。娛楽と消費としての語学学習には1) Serious Leisure （真剣な余暇活動）（Stebbins，2007）と2）Casual Leisure（カジュアルな余暇活動） （Stebbins， 1997）の 2 種類がある。現在の香港大学専業進修学院の CEF の受給条件に基づくカリ キュラムでは、「知識やスキルを体系的に蓄積していく」Serious Leisure の側面が強く、毎日長 時間の学習時間を費やすことができない学習者にとって大きな負担となっている。香港大学専業進 修学院での日本語コース受講をやめた日本語学習者は「エンターテイメントや楽しみのために活動 を消費する」Casual Leisure の学習者であり、そのような学習者のためには今一度カリキュラム を再考しなければならないのではないだろうか。今後 Serious Leisure と Casual Leisure の2 種類の余暇活動に対応できるカリキュラム作りを模索しなければならないであろう。

\section{6. おわりに}

本調査では、香港大学専業進修学院で初級日本語コースを受講したにも関わらず、途中で受講を やめてしまった学習者に対して質問紙調査と半構造化インタビューを行い、香港の生涯学習機関に 
おける社会人学習者の動機減退要因を探った。しかしながら、本調查の質問紙調查に参加した調查 協力者の数は 21 人と少なく、統計学的に有意であるとは言い難い。途中でコース受講を断念してし まった学習者に調查を依頼することはなかなか難しいが、今後は質問紙調查に協力してくれる学習 者の数を増やし、年齢差や指導する教師の母語、学習動機がどのように学習動機減退要因に影響を 与えるのか統計学の手法を用い分析できればと考える。

最後に、本調查に協力してくれた学習者の多くは今後何らかの形で日本語学習を継続したいと考 えており、プログラム運営者、教師はそのニーズにどのように答えるのか考えていかなければなら ないだろう。そして、「余暇活動」として学ぶ日本語学習者にどのようなカリキュラムが適してい るのか、学習者のニーズ分析などを行い、今後の実践に生かしていきたい。

$* * * * * * * * * * * * * * * * * * * * * * * * * * * * * *$

\section{参考文献}

荒井貴和 (2004)「何が外国語学習のやる気を失わせるか一動機減退の要因とそれに対する学習者の

反応に関する質的調查」『東洋学園大学紀要』 $12,39-47$.

垣田直巳 (2005)『英語の学習意欲』英語教育学モノグラフ・シリーズ、大修館 木山登茂子・中野貴子・周宏陽・上田早苗・望月貴子・蘇凱達・青山玲二郎 (2011) 「2010年香港日

本語学習者背景調查報告」『日本学刊』14, 176-195.

国際交流基金(2011)『海外の日本語教育の現状 日本語教育機関調查・2009年 概要』

$\langle h t t p$ ://www.jpf.go.jp/j/japanese/survey/result/index.htm1〉（2011年9月23日）

瀬尾匡輝 (2011)「香港の日本語生涯学習者の動機づけの変化一修正版グラウンデッド・セオリー・

アプローチを用いた分析から探る」『日本学刊』14，16-39.

山森光陽 (2004)「中学1年生の 4 月における英語学習に対する意欲はどこまで継続するか」『教育心 理学研究』52, 71-82.

米本和弘 (2009)「生涯教育における日本語能力試験の位置づけ一香港の生涯教育の事例研究」

『2009年度日本語教育学会秋季大会予稿集』159-164.

Bandura, A. (1997). Self-efficacy: The exercise of control. New York: Freeman.

Cambridge: Cambridge University Press.

Deci, E. L., \& Ryan, R.M. (2002). Intrinsic motivation and self-determination in human behavior. New York: Plenum.

Covington, M.V. (1998). The will to learn: A guide for motivating young people.

Dörnyei, Z. (2001a). Motivational strategies in the language classroom.

Cambridge: Cambridge University Press. 
Dörnyei, Z. (2001b). Teaching and researching motivation. Harlow: Longman.

Freire, P. (1970). Pedagogy of the oppressed. London: Continuum Publishing Company.

Hasegawa, A. (2004). Student demotivation in the foreign language classroom. Takushoku Language Studies, 12, 119-136.

Knowles, M. S. (1968). Andragogy, not pedagogy! Adult Leadership, 16, 350-352.

Kubota, R. (2011). Learning a foreign language as leisure and consumption: Enjoyment, desire, and the business of eikaiwa. International Journal of Bilingual Education and Bilingualism, 14, 473-488.

Locke, E. A., \& Latham, G.P. (1990). A theory of goal setting and task performance. Englewood Cliffs, NJ: Prentice Hall.

Nakata, Y. (2006). Motivation and experience in foreign language learning. 0xford: Peter Lang.

Norton Peirce, B. (1995). Social identity, investment, and language learning. TESOL Quarterly, 29(1), 9-31.

Richards, K. (2003). Qualitative inquiry in TESOL. New York, NY: Palgrave Macmillan.

Stebbins, R.A. (1997). Casual leisure: A conceptual statement. Leisure Studies, $16, \quad 17-25$.

Stebbins, R. A. (2007). Serious leisure: A perspective of our time. New Brunswick, NJ: Transaction Publishers.

Tsuchiya, M. (2006) Profiling of lower achievement: English learners at college in terms of demotivating factors. Annual Review of English Language Education in Japan, 17, 171-180.

Weiner, B. (1992). Human motivation: Metaphors, theories and research. Newbury Park, CA: Sage.

Zang, Q. (2007). Teacher misbehaviors as learning demotivators in college classroom: A cross-cultural investigation in China, Germany, Japan, and the United States. Communication Education, 56(2), 209-227. 


\section{資料 1 質問紙}

\section{Demotivation of learners at the continuing education program 生涯学習機関で学ぶ学習者の動機減退要因に関する調査}

\section{目的 :}

毎年 1,000 人近くがゼロ初級として日本語学習を香港大学専業進修学院で勉強し始めているが、 その中の約 4 割が途中でやめてしまう。本調查では、学習を途中でやめてしまった学習者を対象と し、学ぶ自由と学ぶことをやめる自由のある成人である “生涯”学習者がなぜ日本語学習をやめてし まったのか探る。なお、回答者の個人名が特定されることは決してなく、その使用目的はプログラ ム内容の向上及び言語教育に関する研究目的に限る。

1. 性別 Gender

a. 女 Female

b. 男 Male
2. 年齢 Age
a. 19 歳以下
b. $\quad 20 \sim 24$ 歳
c. $\quad 25 \sim 29$ 歳
d. $\quad 30 \sim 34$ 歳

$\begin{array}{ll}\text { e. } & 35 \sim 40 \text { 歳 } \\ \text { f. } & 41 \sim 45 \text { 歳 } \\ \text { g. } & 46 \sim 50 \text { 歳 } \\ \text { h. } & 51 \sim 55 \text { 歳 }\end{array}$

3. 出生地

a. 香港

b. 中国本土

4. 先生

a. 日本人先生の名前（もし覚えていれば）：

b. 香港人

5. いつごろクラスをやめましたか
a. 2010 年 9 月
e. 2011 年 1 月
i. 2011 年 5 月
b. 2010 年 10 月
f. 2011 年 2 月
j. 2011 年 6 月
c. 2010 年 11 月
g. 2011 年 3 月
k. 2011 年 7 月
d. 2010 年 12 月
h. 2011 年 4 月 
6. 日本語学習を始めたきっかけ（複数回答可）
a. 日本の文化（文学や歴史）を知りたかった
1. 昇進のため
b. 日本の文化（アニメ、漫画、ポップカ
m. 日本旅行のため ルチャー）を知りたかった
n. 日本との親善・交流のため（短期訪問）
c. 日本の政治・社会経済を知りたかった
o. 日本語でコミュニケーションができる
d. 日本の科学技術を知りたかった ようになりたい
e. 日本の食べ物について知りたかった
p. 継承語として学ぶため
f. 日本のファッションについて知りたかった
q. 日本語自身に興味がある
g. 大学や資格試験の受験の準備のため
r. 国際理解 - 異文化理解の一環として
h. 日本へ留学のため
s. 家族・親族等周囲の人に勧められたため
i. 今の仕事のため
t. 日本が好きだから
j. 就職のため
u. その他（具体的に書いてください）
k. 日本で働きたかった

7. 香港大学専業進修学院で日本語を勉強し始めたきっかけ（複数回答可）
a. 值段が安かった
f.上級まであった
b. うちから近かった
g. 友達に蔴められた
c. 会社から帰るのに便利な場所だった
h. 先生がいいと聞いた
d. 通いやすい時間帯だった
i. 香港大学付属の学校である
e. 週に一回 3 時間という授業の長さがよ
j. その他（具体的に書いてください） かった

8. 香港大学専業進修学院での日本語学習をやめた理由（複数回答可）
a. 声に出して発音するのが恥ずかしかった
g. クラスの人数が少なすぎて、すぐに質 問が回ってくるのが嫌だった
b. 質問されて答えを間違えるのが嫌だった
c. 単語を覚えるのが面倒だった
h. 文法に関する学習が多かった
d. 日本語の文法がわかりにくかった
i. 日本語能力試験のための勉強が多かった
e. 日本語を話す自分やクラスメートと日本
j. 日本語能力試験のための勉強が少なかっ 語を話すことに違和感を感じた た

f. クラスの人数が多すぎて、十分練習できない

k. 教科書を暗記させられることが多かった 
1. 定期テスト（中間テスト、クイズ）の 成績が悪かった

m. 宿題が多かった

n. 宿題が少なかった

o. 勉強する内容が多すぎた

p. 勉強する内容が少なすぎた

q. 日本語の予習・復習方法がわからなかった

r. 先生の日本語の発音が悪かった

s. 先生の説明がわかりにくかった

t. 先生の話す広東語（中国語・英語）の 発音がわかりにくかった

u. 先生が生徒の間違いを馬鹿にした態度を とった

v. 先生の一方的な説明が多かった

w. 先生が感情的にどなったり怒ったりした

x. 授業で扱う文型がいつ使われるかわか らなかった

y. 授業で扱う内容に興味がなかった

z. 授業で扱う文型が難しかった

a. 3 時間のクラスは長すぎた

bb. 週 1 回の授業ではすぐ忘れてしまい、 学習するのが困難だった

cc. 学習ペースが速すぎた

dd. 学習ペースが遅すぎた

ee. 友達と比べてテストの得点が取れなかった

ff. クラスメートが嫌いだった

gg. クラスの雰囲気が嫌だった

hh. クラスのレベルが高すぎる

ii. クラスのレベルが低すぎる

jj. 授業の進め方が単調だった

$k \mathrm{k}$. 問題の繰り返し練習が多すぎた
11. 問題の繰り返し練習が少なすぎた

mm. 間違いや質問に対する教師の対応が悪い

nn. 教師が一方的な態度を取る

oo. 教師と意思疎通がうまくいなかい

pp. 友達がクラスをやめたので、自分もやめた

qq. 日本語を学ぶ目的がわからなくなった

rr. 日本語に興味がなくなった

ss. 日本文化に興味がなくなった

tt. 日本の社会に興味がなくなった

uu. 日本語ができる必要はないと感じるよう になった

vV. 自分が目標としていた日本語能力を獲 得できた

ww. 定期テスト（中間テスト、クイズ）の 内容が難しい

$\mathrm{xx}$. 定期テスト（中間テスト、クイズ）の 内容が実生活と結びつかない

yy. 教室内で日本語でコミュニケーション する機会がなかった

zz. 教室外で日本語でコミュニケーション する機会が無かった

aаa. 仕事が変わって、通えなくなった

bbb．仕事が忙しくなって、通えなくなった

ссс. 家庭の事情で、通えなくなった

ddd. 子どもの世話をしなければならなくなった

eee. 他の学校へ行くことにした

fff. 他の学習方法で学ぶことにした

ggg. 日本・日本人が嫌いになった

hhh. その他（具体的に書いてください） 
瀬尾 匡輝/陳德奇/司徒 棟威: なぜ日本語学習をやめてしまったのか

一香港の社会人教育機関の学習者における動機減退要因の一事例一

9. 今後も日本語を勉強するつもりがありますか。
a. はい、絶対に（どこで勉強しようと思
b. はい、いつか時間があれば いますか）
c. いいえ、絶対にしない

10. 自由にコメントを書いてください。（プログラムで特によかった点、逆にそう思わなかった点 など、その他何でも) 